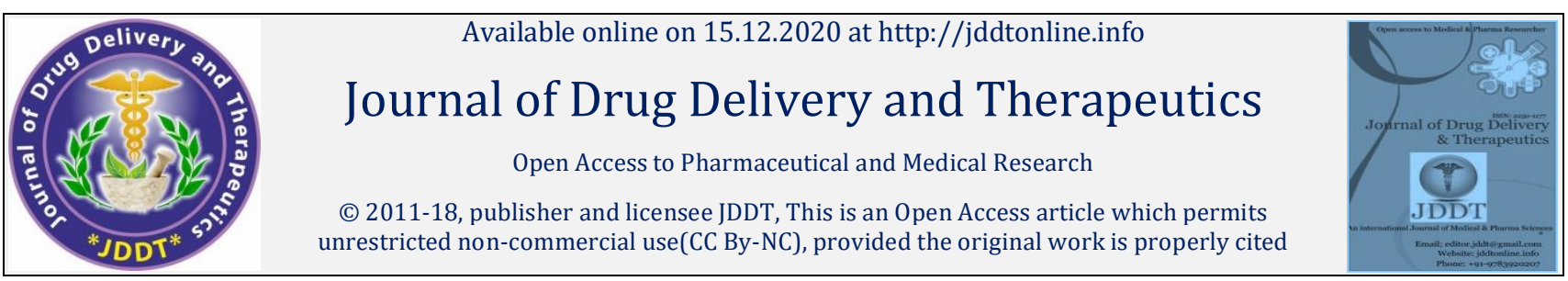

Open Access

\title{
Genetics of Colorectal Cancer: Role of p53
}

\author{
Rajashri Champanery ${ }^{*}$, Drashti Joshi ${ }^{2}$ \\ ${ }^{1}$ Biochemistry Department, Gujarat University, Ahmedabad, Gujarat, India \\ ${ }^{2}$ Analytical and environmental services, Vadodara, Gujarat India
}

\begin{abstract}
The tumor suppressor TP53 gene is one of the most frequently mutated in different types of human cancer. Particularly in colorectal cancer (CRC), it is believed that TP53 mutations play a role in the adenoma-carcinoma transition of tumors during pathological process. The TP53 mutation is the key step driving the transition from adenoma to adenocarcinoma. The functional roles of TP53 mutation in tumor development have been comprehensively investigated. In this mini review, we comprehensively summarize the p53 mutants in CRC progression and discuss the current strategies for p53 mutants in malignancies.
\end{abstract}

Keywords: p53 mutants, colorectal cancer, Tp53 mutation

Article Info: Received 06 Oct 2020; $\quad$ Review Completed 18 Nov 2020; $\quad$ Accepted 28 Nov 2020; $\quad$ Available online 15 Dec 2020

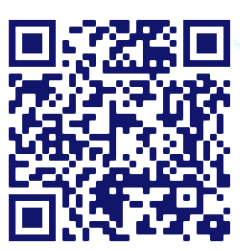

Cite this article as:

Champanery R, Joshi D, Genetics of Colorectal Cancer: Role of p53, Journal of Drug Delivery and Therapeutics. 2020; 10(6-s):183-185 http://dx.doi.org/10.22270/jddt.v10i6-s.4423

*Address for Correspondence:

Rajashri Champanery, Biochemistry Department, Gujarat University, Ahmedabad, Gujarat, India

\section{Introduction}

Colorectal cancer is a major cause of cancer death and, in most cases, develops from a pre-existing adenoma and then adenoma-carcinoma sequence ${ }^{1-3}$.This sequence is characterized by an accumulation of molecular genetic alterations causing disorders in cell growth, differentiation and apoptosis ${ }^{4-6}$. It is generally believed that the balance between the rates of cell growth and apoptosis maintains intestinal epithelial cell homeostasis and that during cancer development this balance gets progressively disturbed 7,8 . Apoptosis, or programmed cell death, plays an important role in many physiologic and pathologic processes $9-11$. Amongst others, an important function of apoptosis lies in the elimination of damaged cells. There is increasing evidence to support the hypothesis that failure of apoptosis may be an important factor in the evolution of colorectal cancer and its poor response to chemotherapy and radiation. It has been firmly established that colorectal carcinogenesis is characterized by a stepwise accumulation of genetic alterations ${ }^{12-14}$. Most studies have focused on the possible roles of the tumour suppressor genes adenomatous polyposis coli (APC) and p53 and the oncogene K-RAS, which will be briefly discussed below ${ }^{15,16}$.

\subsection{Role of APC in CRC:}

The APC gene product is a $312 \mathrm{kD}$ protein consisting of 2843 amino acids. Mutations in the APC gene have been implicated in both sporadic and familial colorectal Neoplasia 16,17 .

ISSN: 2250-1177
The frequency of APC mutations is similar in colonic adenomas and carcinomas (approximately 60\%), suggesting that APC mutations may be an early or even the initiating event in the process of colorectal carcinogenesis ${ }^{18,19}$. The functional significance of the APC gene probably lies not only in the regulation of apoptosis, but also in control of cell cycle progression, migration and differentiation. APC is a key player in the regulation of the Wnt signaling pathway. It has been shown that in normal cells, the APC protein resides in a large complex with axin, glycogen synthase kinase $3 ß$ (GSK3b) and ß-catenin. Loss of tumour suppressor APC gene and APC protein function leads to $B$-catenin accumulation in the nucleus which leads to cell proliferation and cancer ${ }^{20,21}$.

\subsection{Role of $p 53$ in CRC:}

$p 53$, also known as TP53 or tumour protein is a gene that codes for a $p 53$ protein which regulates the cell cycle and hence functions as tumour suppressor. The human $p 53$ plasmid is located on the seventeenth chromosome (17p13.1). It plays an important role in cell cycle control and apoptosis. Defective $p 53$ could allow abnormal cells to proliferate, resulting in cancer. DNA damage and other stress signals may trigger the increase of $p 53$ proteins, which have three major functions: growth arrest, DNA repair and apoptosis. It is very important for cells in multicellular organisms to suppress cancer ${ }^{22-24} . p 53$ has been described as "the guardian of the genome", referring to its role in conserving stability by preventing genome mutation 10,25,26. Its product, the $p 53$ protein, may respond to DNA damage by 
triggering either growth arrest during G1 or G2 phase of the cell cycle or programmed cell death. In this manner, $p 53$ may protect the normal cell from proceeding to replicate damaged DNA Figure 1 . The wild-type $p 53$ protein, but not the mutant, can initiate apoptosis 11,27,28.

Mutations of the $p 53$ gene occur in various human tumours, including colorectal cancer. Deletions and mutations of the $p 53$ gene can be detected in up to $85 \%$ of colorectal tumours and usually occur during the transition from adenoma to adenocarcinoma. Vogelstein et al. reported that a loss of a large portion of chromosome $17 \mathrm{p}$ was seen in $75 \%$ of colorectal carcinomas. The loss of the $p 53$ gene is probably the key event in the conversion of a severely dysplastic adenoma into a carcinoma ${ }^{29,30}$. Thus, mutations of the $p 53$ gene occur late in the adenoma-carcinoma sequence and are more common in carcinomas that have invaded past the mucosa. It has also been found that $p 53$ has profound effects on responses to chemotherapeutic drugs used in colorectal cancer, and that these effects vary considerably depending on the drug. It has been postulated that tumours with mutations of the $p 53$ gene may be more resistant to chemotherapeutic agents and have a higher mutation rate which allows for earlier metastasis as compared to tumours with intact $p 53$ gene 31,32 .

\subsection{Other genes important in CRC:}

1) KRAS in CRC: Activation of KRAS occurs when it binds GTP at the expense of GDP, mutation of KRAS commonly maintains the protein in its GTP bound state and therefore renders it constitutively active. Up to $50 \%$ of sporadic colorectal tumours are found to contain mutations of the KRAS oncogene 33,34 .

2) PI3-Kinase pathway in CRC: Like the MAPK pathway the $\mathrm{PI}_{3}$-Kinase pathway is downstream of RAS and activation of the pathway can promote a wide range of cellular functions, including cell growth, survival and motility 35,36 .

\section{(a) Growth Arrest}

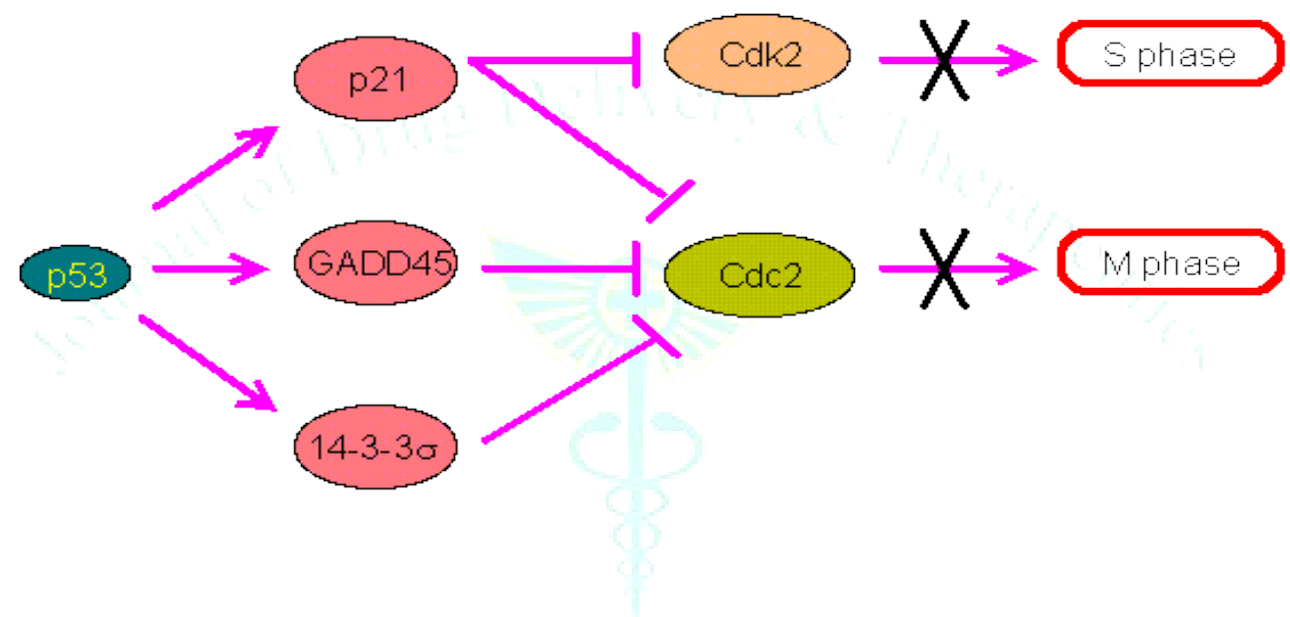

(b) Apoptosis

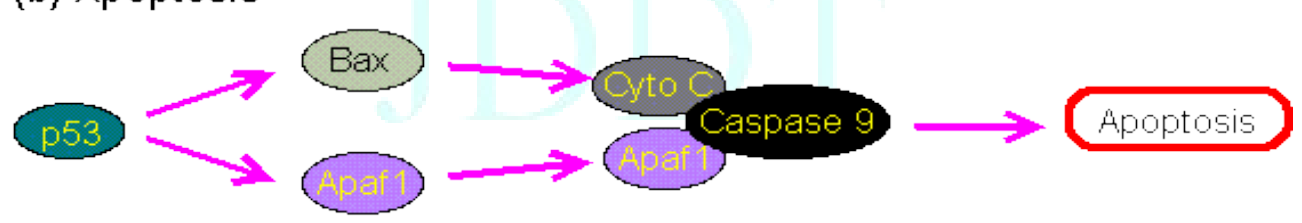

Figure 1: The roles of p53 in growth arrest and apoptosis.

(a) The cell cycle progression into the $\mathrm{S}$ phase requires the enzyme Cdk2, which can be inhibited by p21. The progression into the $\mathrm{M}$ phase requires Cdc2 which can be inhibited by p21, GADD45, p53 regulates the expression of these inhibitory proteins to induce growth arrest. (b) Apoptosis can be induced by the binding of Caspase 9 to cytochrome c and Apaf1. p53 may activate the expression of Apaf1 and Bax 37,38 .

\section{Conclusion}

There is no doubt that reactivation and restoration of p53 function have great potential as a novel therapeutic strategy in CRC. However, the majority of molecules that lead to cell cycle arrest and apoptosis in CRC cells, has only been tested in cell lines and animal models, and has yet to enter in clinical trials. In addition, it is clear that mutant p53 promotes various oncogenic events. Nevertheless, the critical mechanisms are still not completely understood. Riding on the last 30 years of intensive research in p53 area, this is now the time to harvest the fruits from this body of work and translate our knowledge of p53 into clinical practice for CRC patients.

\section{References}

1. Midgley R, Kerr D. Colorectal cancer. Lancet (London, England). 1999; 353(9150):391-9.

2. Kinzler KW, Vogelstein B. Lessons from Hereditary Colorectal Cancer. Cell. 1996; 87(2):159-70.

3. Vhora I, Patil S, Bhatt P, Gandhi R, Baradia D, Misra A. Receptortargeted drug delivery: current perspective and challenges. Ther Deliv. 2014; 5(9):1007-24.

4. Kinzler KW, Vogelstein B. Lessons from hereditary colorectal cancer. Cell. 1996; 87(2):159-70.

5. Kerr JF, Winterford CM, Harmon BV. Apoptosis. Its significance in cancer and cancer therapy. Cancer. 1994; 73(8):2013-26.

6. Achim M, Tomuta I, Vlase L, Iuga C, Moldovan M, Leucuta SE. Paclitaxel-loaded poly(lactic-co-glycolic acid) microspheres: 
preparation and in vitro evaluation. Journal of Drug Delivery Science and Technology. 2008; 18(6):410-6.

7. Nishihara H, Kizaka-Kondoh S, Insel PA, Eckmann L. Inhibition of apoptosis in normal and transformed intestinal epithelial cells by cAMP through induction of inhibitor of apoptosis protein (IAP)-2. Proc Natl Acad Sci U S A. 2003; 100(15):8921-6.

8. Abraha AM, Ketema EB. Apoptotic pathways as a therapeutic target for colorectal cancer treatment. World J Gastrointest Oncol. 2016; 8(8):583-91.

9. Thompson CB. Apoptosis in the pathogenesis and treatment of disease. Science (New York, NY). 1995; 267(5203):1456-62.

10. Angelova A, Garamus VM, Angelov B, Tian Z, Li Y, Zou A. Advances in structural design of lipid-based nanoparticle carriers for delivery of macromolecular drugs, phytochemicals and anti-tumor agents. Advances in colloid and interface science. 2017; 249:331-45.

11. Dhanikula AB, Panchagnula R. Localized paclitaxel delivery. International journal of pharmaceutics. 1999; 183(2):85-100.

12. Ilyas M, Straub J, Tomlinson IP, Bodmer WF. Genetic pathways in colorectal and other cancers. European journal of cancer (Oxford, England : 1990). 1999;3 5(3):335-51.

13. Bhatt P, Khatri N, Kumar M, Baradia D, Misra A. Microbeads mediated oral plasmid DNA delivery using polymethacrylate vectors: an effectual groundwork for colorectal cancer. Drug Delivery. 2015; 22(6):849-61.

14. Oake A, Bhatt P, Pathak YV. Understanding Surface Characteristics of Nanoparticles. In: Pathak YV, editor. Surface Modification of Nanoparticles for Targeted Drug Delivery. Cham: Springer International Publishing; 2019. p. 1-17.

15. Aberle H, Bauer A, Stappert J, Kispert A, Kemler R. beta-catenin is a target for the ubiquitin-proteasome pathway. The EMBO journal. 1997; 16(13):3797-804.

16. Martin YC. Exploring QSAR: Hydrophobic, Electronic, and Steric Constants C. Hansch, A. Leo, and D. Hoekman. American Chemical Society, Washington, DC. 1995 . Xix +348 pp. $22 \times 28.5$ $\mathrm{cm}$. Exploring QSAR: Fundamentals and Applications in Chemistry and Biology. C. Hansch and A. Leo. American Chemical Society, Washington, DC. 1995 . Xvii +557 pp. $18.5 \times$ 26 cm. ISBN 0-8412-2993-7 (set). \$99.95 (set). Journal of Medicinal Chemistry. 1996; 39(5):1189-90.

17. Seedher N, Bhatia S. Solubility enhancement of Cox-2 inhibitors using various solvent systems. AAPS PharmSciTech. 2003;4(3):E33-E.

18. Yao $\mathrm{X}$, Panichpisal $\mathrm{K}$, Kurtzman N, Nugent K. Cisplatin Nephrotoxicity: A Review. The American Journal of the Medical Sciences. 2007; 334(2):115-24.

19. Ehrlich P, Himmelweit F. The collected papers of Paul Ehrlich : in four volumes, including a complete bibliography. London; New York: Pergamon Press; 1956.

20. Carstens MG, de Jong PH, van Nostrum CF, Kemmink J, Verrijk R, de Leede LG, et al. The effect of core composition in biodegradable oligomeric micelles as taxane formulations. European journal of pharmaceutics and biopharmaceutics : official journal of Arbeitsgemeinschaft fur Pharmazeutische Verfahrenstechnik eV. 2008; 68(3):596-606.

21. Lalani R, Misra A, Amrutiya J, Patel H, Bhatt P, Patil SK. Approaches and Recent Trends in Gene Delivery for Treatment of Atherosclerosis. Recent Pat Drug Deliv Formul. 2016; 10(2):141-55.
22. Bae KH, Lee JY, Lee SH, Park TG, Nam YS. Optically Traceable Solid Lipid Nanoparticles Loaded with siRNA and Paclitaxel for Synergistic Chemotherapy with In situ Imaging. Advanced Healthcare Materials. 2013; 2(4):576-84.

23. Bao G, Mitragotri S, Tong S. Multifunctional Nanoparticles for Drug Delivery and Molecular Imaging. Annual Review of Biomedical Engineering. 2013; 15(1):253-82.

24. Patil S, Bhatt P, Lalani R, Amrutiya J, Vhora I, Kolte A, et al. Low molecular weight chitosan-protamine conjugate for siRNA delivery with enhanced stability and transfection efficiency. RSC Advances. 2016; 6(112):110951-63.

25. Levine AJ, Oren $M$. The first 30 years of $p 53$ : growing ever more complex. Nature reviews Cancer. 2009; 9(10):749-58.

26. Bhatt P, Lalani R, Vhora I, Patil S, Amrutiya J, Misra A, et al Liposomes encapsulating native and cyclodextrin enclosed paclitaxel: Enhanced loading efficiency and its pharmacokinetic evaluation. International Journal of Pharmaceutics. 2018; 536(1):95-107.

27. Siegl-Cachedenier I, Muñoz P, Flores JM, Klatt P, Blasco MA. Deficient mismatch repair improves organismal fitness and survival of mice with dysfunctional telomeres. Genes Dev. 2007; 21(17):2234-47.

28. Zhou J, Atsina K-B, Himes BT, Strohbehn GW, Saltzman WM. Novel delivery strategies for glioblastoma. Cancer J. 2012; 18(1):89-99.

29. Goel A, Baboota S, Sahni JK, Ali J. Exploring targeted pulmonary delivery for treatment of lung cancer. Int J Pharm Investig. 2013; 3(1):8-14.

30. Lalani R, Misra A, Amrutiya J, Patel H, Bhatt P, Patel V. Challenges in Dermal Delivery of Therapeutic Antimicrobial Protein and Peptides. Curr Drug Metab. 2017; 18(5):426-36.

31. Kawai K, Sunami E, Tanaka J, Tanaka T, Kiyomatsu T, Nozawa $H_{\text {, }}$ et al. Synchronous colorectal malignancy and abdominal aortic aneurysm treated with endovascular aneurysm repair followed by laparoscopic colectomy. Int Surg. 2015; 100(4):600-3.

32. Xie J, Xiao D, Zhao J, Hu N, Bao Q, Jiang L, et al. Mesoporous Silica Particles as a Multifunctional Delivery System for Pain Relief in Experimental Neuropathy. Adv Healthc Mater. 2016; 5(10):1213-21.

33. Bos JL. ras oncogenes in human cancer: a review. Cancer research. 1989; 49(17):4682-9.

34. Bhatt $P$, Narvekar $P$, Lalani R, Chougule MB, Pathak Y, Sutariya V. An in vitro Assessment of Thermo-Reversible Gel Formulation Containing Sunitinib Nanoparticles for Neovascular Age-Related Macular Degeneration. AAPS PharmSciTech. 2019; 20(7):281.

35. Courtney KD, Corcoran RB, Engelman JA. The PI3K pathway as drug target in human cancer. Journal of clinical oncology : official journal of the American Society of Clinical Oncology. 2010; 28(6):1075-83.

36. Shahiwala A, Misra A. In-Vitro and In-Vivo Tools in Drug Delivery Research for Optimum Clinical Outcomes2018.

37. Sinicrope FA, Roddey G, McDonnell TJ, Shen Y, Cleary KR, Stephens LC. Increased apoptosis accompanies neoplastic development in the human colorectum. Clinical Cancer Research. 1996; 2(12):1999.

38. Vhora I, Lalani R, Bhatt P, Patil S, Patel H, Patel V, et al. Colloidally Stable Small Unilamellar Stearyl Amine Lipoplexes for Effective BMP-9 Gene Delivery to Stem Cells for Osteogenic Differentiation. AAPS PharmSciTech 2018; 19:3550-3560. 